\title{
ILLUSTR ATIONS
}

\section{Index Maps}

xvi I. Index of sectional map sheets of the boundary between the United States and Mexico, land boundary section.

xvii 2. Index of sectional map sheets of the boundary between the United States and Mexico, Rio Grande section.

\section{Location Maps}

6I I. The California azimuth line, the Colorado River, and part of the United States-Sonora azimuth line.

88 2. The Rio Grande between the Gulf of Mexico and Eagle Pass.

IO3 3. The land boundary west of the Rio Grande, including the turning point at the $\mathrm{m}^{\circ}$ meridian.

I40 4. The Rio Grande between Agua Verde near the Pecos River and Paso del Norte.

\section{Treaty Maps}

4 FIG. I-r. John Disturnell, Mapa de los Estados Unidos de Méjico.

Io FIG. I-2. Copy of the plan of the port of San Diego by Juan Pantoja.

\section{Boundary Maps}

55 FIG. 2-I. Title panel and commissioners' signatures.

70 FIG. 3-r. U.S. map "No. 54."

72 FIG. 3-2. Mexican map "No. 54."

78 FIG. 3-3. U.S. map "No. 45."

80 FIG. 3-4. Mexican map "No. 45."

82 FIG. 3-5. U.S. map "No. 44." 
84 FIG. 3-6. Mexican map "No. 44."

91 FIG. 3-7. Detail of U.S. map "No. x."

92 FIG. 3-8. Detail of Mexican map "No. I," showing the desembocadura.

95 FIG. 3-9. Detail of Mexican map "No. 1," showing Matamoros and Brownsville.

Io6 Fig. 4-I. U.S. map "No. 48."

I08 FIG. 4-2. Mexican map "No. 48."

IIO FIG. 4-3. Detail of Mexican map "No. 48."

I16 FIG. 4-4. U.S. map "No. 32."

II8 FIG. 4-5. Mexican map "No. 32."

I20 FIG. 4-6. Detail of Mexican map "No. 32."

122 FIG. 4-7. Mexican map "No. 36."

I24 FIG. 4-8. U.S. map "No. 36."

132 FIG. 4-9. Detail of U.S. map "No. 38."

134 FIG. 4-10. Detail of Mexican map "No. 39."

135 F1G. 4-Ir. Detail of U.S. map "No. 41."

136 FIG. 4-12. Detail of Mexican map "No. 41."

144 FIG. 5-1. Detail of Mexican map "No. 28."

146 FIG. 5-2. Detail of U.S. map "No. 28."

I5O FIG. 5-3. Detail of Mexican map "No. 23."

I52 FIG. 5-4. Detail of U.S. map "No. 23."

154 FIG. 5-5. Mexican map "No. 22."

156 Fig. 5-6. U.S. map "No. 22."

I62 FIG. 5-7. Mexican map "No. 8."

164 FIG. 5-8. U.S. map "No. 8."

166 FIG. 5-9. Detail of Mexican map "No. 8."

168 FIG. 5-ro. U.S. "Sheet No. 4, Islands in the Río Bravo del Norte."

172 FIG. 5-II. U.S. map "No. 29."

I74 FIG. 5-12. Mexican map "No. 29."

176 F1G. 5-13. Detail of Mexican map "No. 29."

178 FIG. 5-14. Detail of U.S. map "No. 29." 